\title{
Analisis Potensi Pembangkit Listrik Tenaga Photovoltaic-Wind Turbines Di Pantai Sedari Karawang
}

\section{Analysis of Photovoltaic/Wind Potential Hybrid Power System in Sedari Beach Karawang}

\author{
Eri Widianto ${ }^{1}$, Dian Budhi Santoso ${ }^{2}$, Kardiman ${ }^{3}$, Najmudin Fauji ${ }^{4}$ \\ 1,3,4Program Studi Teknik Mesin, Fakultas Teknik Universitas Singaperbangsa Karawang \\ ${ }^{2}$ Program Studi Teknik Elektro, Fakultas Teknik Universitas Singaperbangsa Karawang \\ Jalan H.S. Ronggowaluyo, Telukjambe Timur, Karawang, Indonesia 41361 \\ *Email: eri.widianto@ft.unsika.com
}

\begin{abstract}
DOI;
10.30595/jrst.v3i1.3653

ABSTRAK

Histori Artikel:

Pembangkit listrik tenaga surya dan angin merupakan pembangkit listrik berbasis energi terbarukan. Penelitian ini bertujuan untuk mengetahui konfigurasi pembangkit terbaik menggunakan Software HOMER (Hybrid Optimization Model for Energy Renewable) di Pantai Sedari, Kecamatan Cibuaya, Karawang. Pantai Sedari, Cibuaya terletak pada

Diajukan:

$05 / 12 / 2018$ koordinat $5^{\circ} 57.6^{\prime} S$ dan $107^{\circ} 18.4$ E. Data potensi energi surya dan angin didapatkan dari retSCREEN NASA. Hasil penelitian diperoleh potensi energi matahari rata-rata sebesar $5,17 \mathrm{kWh} / \mathrm{m}^{2} /$ hari dan potensi tenaga angin

Direvisi: sebesar 3,50 m/s. Desain pembangkit listrik hybrid menggunakan HOMER 03/03/2019 terdiri dari PV 0,075 kW, G1 $1 \mathrm{~kW}$ dan Gen $2,7 \mathrm{~kW}$ dengan converter $25 \mathrm{~kW}$, diperoleh Biaya Net Total Masa Kini (Total Net Present Cost/NPC) sebesar \$

Diterima: $29 / 03 / 2019$ $82.080,25$. Penelitian ini memberikan informasi penting tentang potensi energi terbarukan (surya dan angin) khususnya di daerah Pantai Sedari Kabupaten Karawang.
\end{abstract}

Kata Kunci: HOMER, hybrid energy, surya dan angin

\begin{abstract}
Solar energy and wind power are a renewable energy-based power plant. This study aims to determine the best configurations by software HOMER (Hybrid Optimization Model for Energy Renewable) in Sedari beach, Cibuaya-Karawang. Sedari, Cibuaya beach is located at coordinates $5^{\circ} 57.6^{\prime} \mathrm{S}$ dan $107^{\circ} 18.4 \mathrm{E}$. The potential solar and wind power data from retSCREEN NASA. The result obtained by the potential of solar energy an average of $5.17 \mathrm{kWh} / \mathrm{m}^{2} /$ day and the potential of wind power average of $3.50 \mathrm{~m} / \mathrm{s}$. The design of a hybrid power plant using HOMER consists of PV 0,075 kW, G1 $1 \mathrm{~kW}$ and Gen 2,7 $\mathrm{kW}$ with a converter of $25 \mathrm{~kW}$, obtained a Total Net Present Cost (NPC) of \$82,080.25. This research to provide important information about renewable energy (solar and wind), especially in the Sedari Beach, Karawang.
\end{abstract}

Keywords: HOMER, hybrid energy, solar and wind.

\section{PENDAHULUAN}

Sesuai dengan Peraturan Presiden RI no. 5 tahun 2006 tentang Kebijakan Energi Nasional (KEN) yaitu pangsa pasar energi baru dan terbarukan dalam konsumsi energi nasional tahun 2025 ditargetkan mencapai 17\%. Namun demikian pemerintah Indonesia ingin mencapai target yang lebih tinggi dengan mencanangkan visi energi 25/25, dimana pemerintah berkomitmen meningkatkan penggunaan energi baru dan terbarukan sampai $25 \%$ dari 
keseluruhan konsumsi energi pada tahun 2025 dan juga tercapainya elastisitas energi lebih kecil dari satu. Pertumbuhan penduduk yang tinggi menyebabkan konsumsi energi terus meningkat, tetapi cadangan energi fosil semakin menipis. Diperkirakan potensi batubara Indonesia akan habis 73 tahun lagi, gas bumi 31 tahun, dan energi fosil hanya dapat bertahan 10 tahun lagi (CDIEMR, 2012).

Kabupaten Karawang yang dikenal sebagai daerah lumbung padi nasional sejak puluhan tahun lalu akan kehilangan predikatnya, karena permasalahan petani dan pertanian di kabupaten Karawang masih banyaknya lahan tidur. Pemanfaatan lahan tidur tersebut dengan memberdayaan masyarakat serta mendorong gerakan pertanian dan teknologi pertanian yang ramah lingkungan.

Sumber pembangkit listrik dari energi terbarukan, seperti sinar matahari (energi surya) tersedia melimpah dan hampir merata di seluruh wilayah Indonesia. Alat (device) yang mampu merubah energi surya menjadi energi listrik secara langsung dikenal dengan sel surya (solar cell). Sel surya sering disebut pula sebagai Pembangkit Listrik Tenaga Surya (PLTS) atau sel PV. Energi surya adalah salah satu sumber energi yang ramah lingkungan dan sangat menjanjikan pada masa yang akan datang, karena tidak ada polusi yang dihasilkan selama proses konversi energi, dan juga sumber energinya banyak tersedia di alam (Zhou \& Abdullah, 2017).

Wilayah Indonesia terletak di garis khatulistiwa dengan penyinaran matahari ratarata $8 \mathrm{jam} / \mathrm{hari}$ dengan intensitas radiasi matahari rata-rata sekitar $4,80 \mathrm{kWh} / \mathrm{m}^{2} /$ hari [5]. (Sitompul, 2011). Sumber energi surya ini dapat dikembangkan menjadi Pembangkit Listrik Tenaga Sel Surya yang merupakan salah satu solusi yang dapat dipertimbangkan sebagai salah satu pembangkit listrik alternatif (Effendi, 2012). Wind turbine merupakan pembangkit listrik yang mengubah energi mekanis dari angin menjadi energi putar pada kincir, kemudian putaran kincir digunakan untuk memutar generator yang akhirnya menghasilkan energi listrik. Wind turbine terdiri dari rotor, kincir/blade, dan generator. Kincir pada turbin angin biasanya terdiri dari dua atau tiga bilah yang masingmasing panjangnya sekitar 10-30 meter. Wind turbine sering dikombinasi dengan Photovoltaic (PV) menggunakan sistem storage berupa baterai dapat melayani satu daerah dengan kapasitas mencapai 25-100 kW (El-Khattam \& Salama,
2004). Pada tahun 2011, Badan Energi Internasional menyatakan bahwa perkembangan teknologi energi surya yang terjangkau, tidak habis dan bersih akan memberikan keuntungan jangka panjang yang besar. Perkembangan ini akan meningkatkan keamanan energi negaranegara melalui pemanfaatan sumber energi yang sudah ada, tidak habis, dan tidak tergantung pada impor, meningkatkan kesinambungan, mengurangi polusi, mengurangi biaya mitigasi perubahan iklim, dan menjaga harga bahan bakar fosil tetap rendah dari sebelumnya (Suharyadi, 2016). Penerapan sistem hybrid pada pembangkit listrik energi baru dan terbarukan menjadi sangat penting dikarenakan semakin berkembangnya distributed generation (DG) di Indonesia. Sistem pembangkit listrik hybrid ini dapat mengatasi permasalahan kelistrikan di Desa Sedari Karawang. Penelitian ini sistem tenaga hibrida dimodelkan berdasarkan ketersediaan dan potensi energi terbarukan yang tersedia.

HOMER (Hybrid Optimization Model for Energy Renewable) adalah perangkat lunak yang tepat digunakan untuk membantu pemodelan dari sebuah sistem tenaga listrik dengan menggunakan berbagai pilihan sumber daya terbaharukan. HOMER dapat digunakan untuk simulasi dalam mengoptimalkan sistem pembangkit tenaga listrik, baik off-grid (standalone) maupun grid-connected yang dapat terdiri atas kombinasi photovoltaic, mikrohidro, battery dan kombinasi sumber energi baru dan terbarukan lainnya serta untuk melayani beban listrik maupun beban thermal. Perangkat lunak HOMER ini dikembangkan oleh The National Renewable Energy Laboratory (NREL), USA yang bekerjasama dengan Mistaya Engineering, dimana hak ciptanya dilindungi oleh Midwest Research Institute (MRI) dan digunakan oleh Departemen Energi Amerika Serikat (DOE) (Lambert, Gilman, \& Lilienthal, 2006).

Beberapa penelitian telah dilakukan diantaranya Anjaneyulu Krothapalli, melakukan studi pemanfaatan sistem pembangkit listrik tenaga hibrida untuk pemurnian air suling di negara bagian Abia, Nigeria dengan memanfaatkan potensi energi surya dan gasifikasi biomassa (Eziyi \& Krothapalli, 2014). Penelitian disertasi Ifegwu Lekwauwa Kalu Eziyi pada daerah-daerah pedesaan di India dan Nigeria (Ifegwu Eziyi, 2013) . Kumar, dkk., (2011) menggunakan HOMER untuk perencanaan pembangkit listrik hibrida di India yaitu di Desa 
Sundargarh. Hasilnya pembangkit listrik hibrida yang terdiri dari 4 sumber (PV, turbin angin, turbin air dan generator) lebih menguntungkan dibanding sistem hibrida yang terdiri dari 3 sumber (tanpa turbin air), karena menurunkan biaya NPC 24\% dan harga listrik /kWh 23\% (Lal, Dash, \& Akella, 2011). Penelitian serupa dilakukan di Iran yaitu di Desa Sheikh Abolhassan. Hasil penelitian bahwa sistem hibrida yang terdiri dari turbin angin dan grid system menurunkan biaya operasional $23 \%$ dan mengurangi emisi karbondioksida $32 \%$ dibanding tetap menggunakan generator diesel (Asrari, Ghasemi, \& Javidi, 2012). Rajoriya dkk.,(2010) juga melakukan penelitian pembangkit listrik hibrida di pedesaan blok Jaunpur zona 4 distrik Tehri Garwal daerah Uttarakhand India. Hasilnya pembangkit listrik hibrida yang optimal menggunakan 5 turbin angin (masing-masing $10 \mathrm{~kW}$ ), baterai 25 unit (6 $\mathrm{V}, 6.94 \mathrm{kWh}$ ), konverter $35 \mathrm{~kW}$ dan generator diesel $65 \mathrm{~kW}$, karena biaya NPC paling rendah (Rajoriya \& Fernandez, 2010).

Dengan HOMER, dapat diperoleh spesifikasi paling optimal dari sumber energi-sumber energi yang mungkin diterapkan. Kita harus memasukkan data load beban, data sumber daya matahari, sumber daya angin dari daerah di mana kita akan membangun BTS (beban), data ekonomi, data constraints, system control inputs, data emisi dan data harga solar. Penelitian ini diharapkan mampu memberikan informasi penting tentang potensi energi terbarukan (energi surya dan angin) khususnya di daerah Pantai Sedari Kabupaten Karawang, guna menciptakan daerah mandiri energi.

\section{METODE PENELITIAN}

Penelitian berjudul "Analisis Potensi Pembangkit Listrik Tenaga Photovoltaic-Wind Turbines di Pantai Sedari" akan dilaksanakan selama 10 bulan dan bertempat di Laboratorium Dasar Fakultas Teknik Universitas Singaperbangsa Karawang. Tahapan penelitian yang akan dilakukan sesuai dengan skema diagram alir pada Gambar 1.

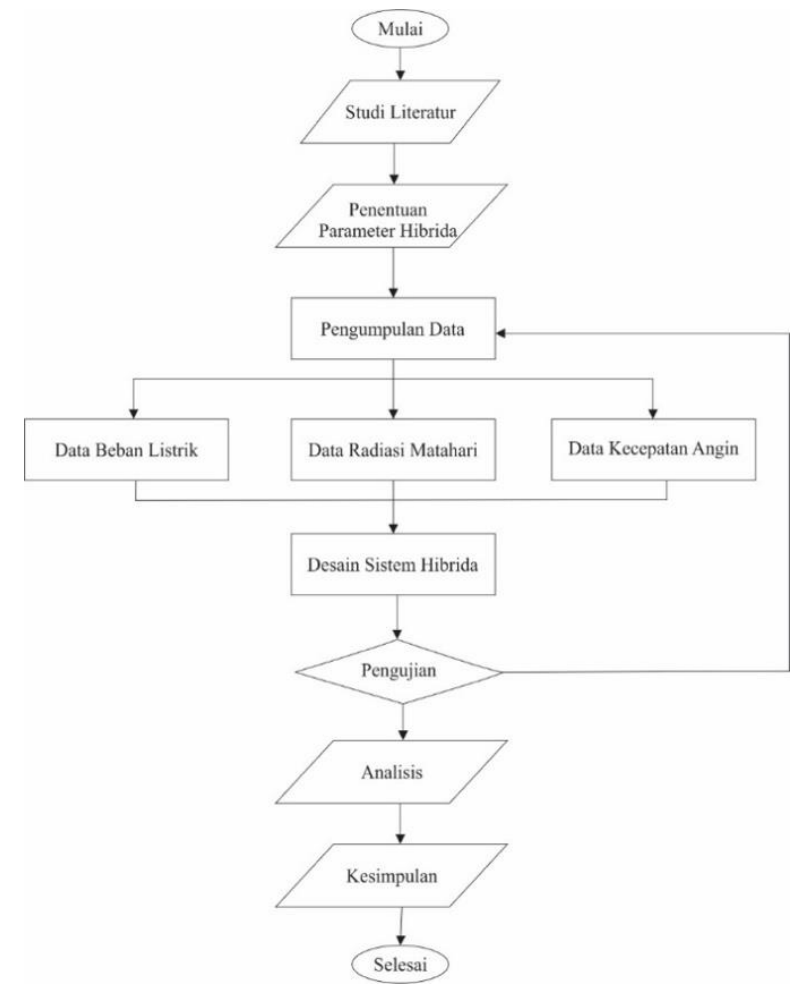

Gambar 1. Diagram alir penelitian

Tahapan penelitian meliputi tahap persiapan, survei potensi serta tahap desain dan simulasi menggunakan HOMER.

a) Tahap Persiapan

Tahap persiapan berupa studi pustaka mengenai sumber energi baru terbarukan, pembangkit listrik tenaga hybrid (matahari dan angin) serta software HOMER.

b) Survei potensi energi

Survei potensi di Pantai Sedari berupa pengumpulan data Load, intensitas matahari, kecepatan angin dan temperatur. Selanjutnya dilakukan penentuan parameter hybrid.

c) Tahap desain simulasi menggunakan HOMER

Tahap desain dan simulasi dengan menginput parameter dan data potensi ke software HOMER, seperti ditunjukkan pada Gambar 2. 


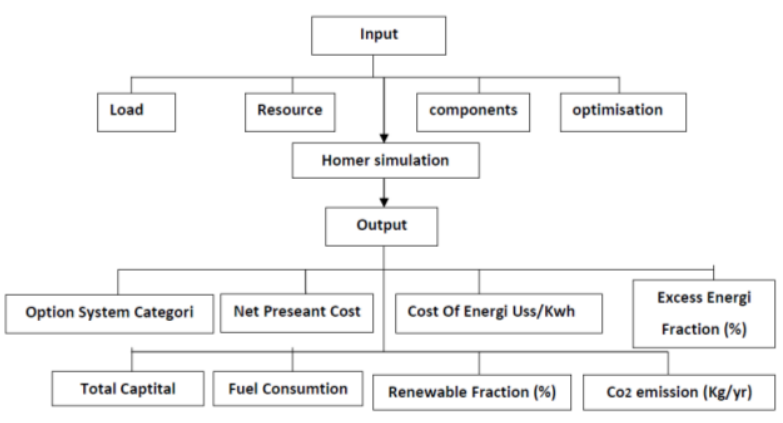

Gambar 2. Skema simulasi HOMER

\section{HASIL DAN PEMBAHASAN}

Telah dilakukan penelitian tentang Analisis Potensi Pembangkit Listrik Tenaga PhotovoltaicWind Turbines di Pantai Sedari Karawang dengan menggunakan Software HOMER (Hybrid Optimization Model for Energy Renewable). HOMER bekerja dalam 3 hal, yaitu simulasi, optimisasi, dan analisa sensitifitas. Hal-hal yang dipertimbangkan dalam merancang suatu sistem hibrid energi menggunakan HOMER di antaranya adalah beban, sumber daya (Resources) dan komponen sistem. Lokasi perencanaan sistem hybrid (matahari dan angin) dilakukan di daerah Pantai Sedari, Kecamatan Cibuaya, Kabupaten Karawang dengan koordinat $5^{\circ 57.6}$ 'S dan 107॰18.4 E, seperti terlihat pada Gambar 3.

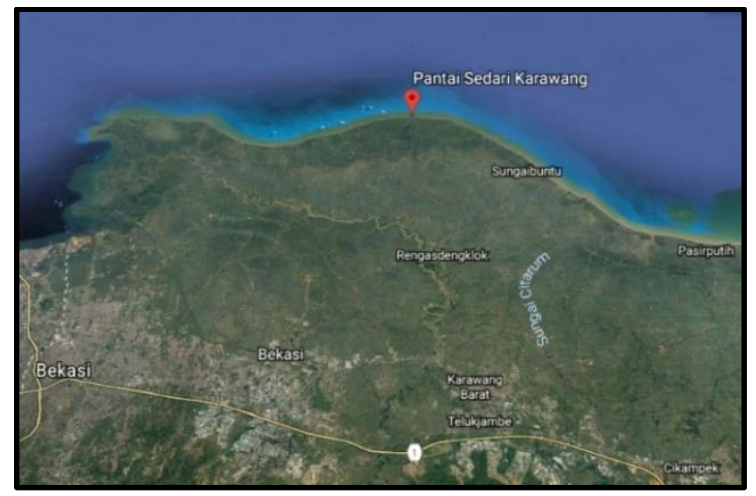

Gambar 3. Lokasi Pantai Sedari, Karawang

\section{A. Potensi Energi Matahari di Pantai Sedari Karawang}

Survei potensi energi bertujuan untuk mencari energi yang yang dapat dimanfaatkan sebagai sistem energi hibryd. Pada penelitian ini mencoba memanfaatkan potensi energi matahari dan energi angin. Potensi energi matahari dapat diketahui dengan menggunakan data radiasi matahari yang diperoleh dari Surface meteorology and Solar Energy (SMSE) dari National Aeronautics and Space Administration (NASA) dengan memasukkan koordinat lokasi Pantai Sedari Karawang. Potensi energi Matahari sebagai sumber energi dinyatakan dalam data indeks kecerahan (Clearnex Incex) dan radiasi sinar matahari (Solar Radiation) yaitu rata-rata global radiasi matahari pada permukaan horizontal, dinyatakan dalam $\mathrm{kWh} / \mathrm{m}^{2}$, untuk setiap hari dalam satu tahun. Data dan grafik potensi energi matahari di Pantai Sedari Karawang ditunjukkan pada Tabel 1 dan Gambar 4.

Tabel 1. Data potensi energi matahari di Pantai Sedari (Data SMSE dari NASA)

\begin{tabular}{lc}
\hline Bulan & $\begin{array}{l}\text { Radiasi } \\
\left(\mathrm{kWh} / \mathrm{m}^{2} / \text { day }\right)\end{array}$ \\
\hline Januari & 4,280 \\
Februari & 4,780 \\
Maret & 5,170 \\
April & 5,220 \\
Mei & 5,090 \\
Juni & 4,900 \\
Juli & 5,260 \\
Agustus & 5,920 \\
September & 6,250 \\
Oktober & 7,730 \\
November & 5,010 \\
Desember & 4,480 \\
Rata-rata & $\mathbf{5 , 1 7}$ \\
\hline
\end{tabular}

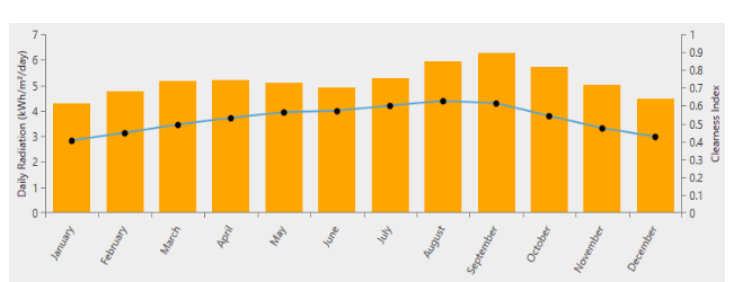

Gambar 4. Grafik potensi energi matahari

Data potensi energi Matahari untuk lokasi PLTH di Pantai Sedari didapatkan indeks daily radiation rata-rata sebesar $5,17 \mathrm{kWh} / \mathrm{m}^{2} /$ hari. Intensitas cahaya yang dihasilkan matahari terhadap daerah tersebut bisa dikatakan cukup untuk menympan energi surya dengan media photovoltaic.

\section{B. Potensi Energi Angin di Pantai Sedari Karawang}

Berdasarkan data potensi energi angin di lokasi Pantai Sedari Karawang, rata-rata kecepatan diukur dari ketinggian $50 \mathrm{~m}$ dari 
permukaan tanah adalah sebesar 3,50 m/s. Data dan grafik potensi energi angin di Pantai Sedari ditunjukkan pada Tabel 2 dan Gambar 5.

Tabel 2. Data potensi energi angin di Pantai Sedari (Data SMSE dari NASA)

\begin{tabular}{lr}
\hline Bulan & \multicolumn{2}{l}{ Kecepatan } & angin \\
$(\mathrm{m} / \mathrm{s})$ & 3,190 \\
Januari & 3,150 \\
Februari & 2,410 \\
Maret & 2,650 \\
April & 3,600 \\
Mei & 4,050 \\
Juni & 5,000 \\
Juli & 5,060 \\
Agustus & 4,340 \\
September & 3,170 \\
Oktober & 2,720 \\
November & 2,630 \\
Desember & $\mathbf{3 , 5 0}$ \\
Rata-rata & \\
\hline
\end{tabular}

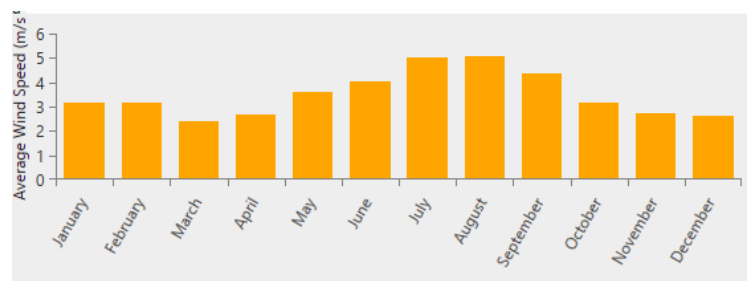

Gambar 5. Grafik potensi energi angin

Energi angin yang diproduksi alam juga dapat menjadi pertimbangan sebagai salah satu faktor keberhasilan produksi energi terbarukan di Pantai Sedari Karawang. Pada Gambar 5 terlihat kecepatan angin rata-rata sebesar $3,5 \mathrm{~m} / \mathrm{s}$ yang merupakan syarat minimum turbin angin untuk dapat mulai berputar. Kecepatan angin di bawah $3 \mathrm{~m} / \mathrm{s}$ hanya terjadi pada Maret, April, November dan Desember. Sebagai sumber energi yang tidak menghasilkan polusi udara dan gas rumah kaca, energi angin potensial dikembangkan di Indonesia terutama di kawasan pesisir dengan angin berlimpah seperti di Pantai Sedari Karawang.

\section{Data Temperatur di Pantai Sedari}

Berikut ini adalah data dan grafik temperatur angin di Pantai Sedari:

Tabel 3. Data temperatur di Pantai Sedari (Data SMSE dari NASA)

\begin{tabular}{lc}
\hline Bulan & Temperatur $\left({ }^{\circ} \mathrm{C}\right)$ \\
\hline Januari & 26,070 \\
Februari & 25,990 \\
Maret & 26,190 \\
April & 26,700 \\
Mei & 27,010 \\
Juni & 26,900 \\
Juli & 26,540 \\
Agustus & 26,450 \\
September & 26,500 \\
Oktober & 26,470 \\
November & 26,390 \\
Desember & 26,270 \\
Rata-rata & $\mathbf{2 6 , 4 6}$ \\
\hline
\end{tabular}

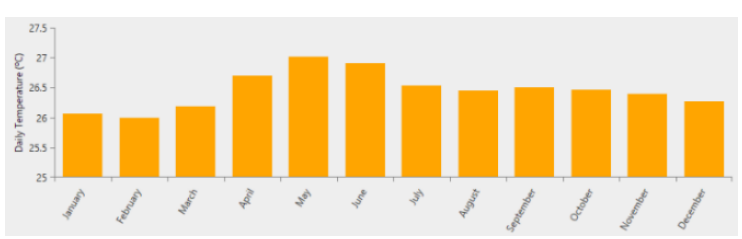

Gambar 6. Grafik temperatur

Temperatur rata-rata di Pantai Sedari Karawang sebesar $26,46^{\circ} \mathrm{C}$, dengan suhu tertinggi $27,010{ }^{\circ} \mathrm{C}$ terjadi pada bulan Mei.

\section{Perancangan dan Hasil Simulasi PLTH}

Dari data Load di Pantai Sedari selanjutnya dilakukan simulasi perancangan pembangkit listrik tenaga hybrid (solar and wind). Bebarapa komponen yang digunakan dalam simulasi yaitu generator, PV, G1 (wind), Load 450 VA dan Converter, ditunjukkan pada Gambar 7. Hasil simulasi HOMER menunjukkan banyak konfigurasi dari beberapa komponen yang dikombinasikan. 
Tabel 4. Hasil simulasi HOMER pembangkit listrik tenaga hybrid (matahari dan angin) di Pantai Sedari

\begin{tabular}{|c|c|c|c|c|c|c|c|c|}
\hline $\begin{array}{l}\text { Konfigur } \\
\text { asi }\end{array}$ & PV (kW) & $\begin{array}{c}\text { G1 } \\
\text { (Wind } \\
\text { ) }\end{array}$ & $\begin{array}{c}\text { Gen } \\
(\mathrm{kW})\end{array}$ & $\begin{array}{l}\text { Convert } \\
\text { er }(k W)\end{array}$ & NPC (\$) & $\operatorname{COE}(\$)$ & $\begin{array}{c}\text { Operatin } \\
\text { g cost } \\
(\$ / y r)\end{array}$ & $\begin{array}{c}\text { Initial } \\
\text { capital } \\
(\$)\end{array}$ \\
\hline Gen & - & , & 2,7 & - & $\begin{array}{c}50758,2 \\
5\end{array}$ & $\begin{array}{c}1,06569 \\
5\end{array}$ & 4266,587 & 1350 \\
\hline PV \& Gen & $\begin{array}{c}0,01562 \\
5\end{array}$ & - & 2,7 & 25 & $\begin{array}{c}74262,8 \\
9\end{array}$ & $\begin{array}{c}1,55918 \\
7\end{array}$ & 4996,946 & $\begin{array}{c}16396,8 \\
8\end{array}$ \\
\hline G1 \& Gen & - & 1 & 2,7 & 25 & $\begin{array}{c}81896,5 \\
2\end{array}$ & $\begin{array}{c}1,71945 \\
9\end{array}$ & 5055,71 & 23350 \\
\hline $\begin{array}{l}\text { PV, G1 } \\
\& \text { Gen }\end{array}$ & 0,075 & 1 & 2,7 & 25 & $\begin{array}{c}82080,2 \\
5\end{array}$ & $\begin{array}{c}1,72331 \\
7 \\
\end{array}$ & 5052,146 & 23575 \\
\hline
\end{tabular}

Konfigurasi yang paling optimal akan menjadi pilihan utama dalam simulasi HOMER, karena hasil yang optimal akan dapat memenuhi kebutuhan listrik skala rumah tangga secara kontinyu di Pantai Sedari. HOMER akan menampilkan hasil berdasarkan nilai NPC yang terendah hingga nilai NPC yang tertinggi. Simulasi yang dirancang menggunakan HOMER dalam penelitian ini terdiri dari dua kategori pengguna daya yaitu $450 \mathrm{VA}$.

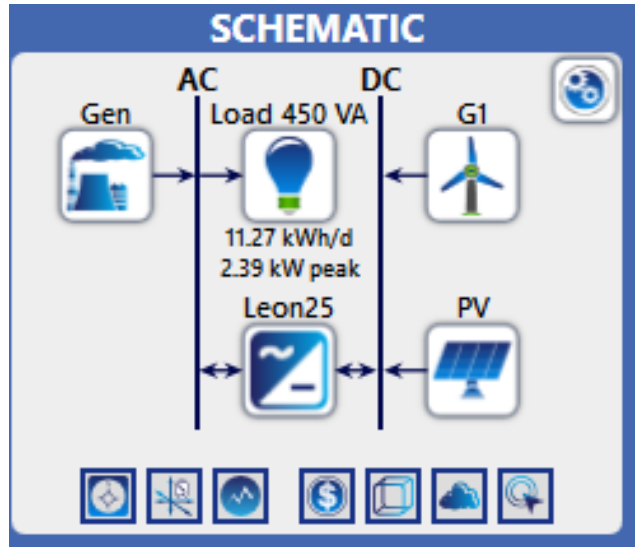

Gambar 7. Model konfigurasi PLTH

Rangkuman hasil simulasi dari dua jenis kategori dan dua sistem yang dirancang menggunakan HOMER ditunjukkan pada Tabel 4 . Pada desain pembangkit listril hybrid terdiri dari PV 0,075 kW, G1 $1 \mathrm{~kW}$ dan Gen 2,7 kW dengan converter $25 \mathrm{~kW}$, diperoleh beberapa parameter antara lain:

a) Biaya Net Total Masa Kini (Total Net Present Cost/NPC) sebesar \$82.080,25. Biaya Net Total Masa Kini (Total Net Present Cost / NPC) adalah keluaran ekonomi yang paling utama untuk nilai suatu sistem PLTH. b) Syarat Batas Biaya Energi (Levelized Cost of Energy/COE) sebesar \$1,723317. Levelized Cost of Energy (COE) didefinisikan sebagai biaya rata-rata per $\mathrm{kWh}$ produksi energi listrik yang terpakai oleh sistem. Untuk menghitung COE biaya produksi energi.

c) listrik tahunan dibagi dengan total energi listrik terpakai yang diproduksi.

d) Initial Capital atau modal awal untuk pengadaan sistem sebesar $\$ 23.575$.

e) Biaya Operasional tahunan operasi dan pemeliharaan sistem sebesar 5.052,146 \$/tahun.

\section{KESIMPULAN}

Dari hasil penelitian yang dilakukan diperoleh beberapa kesimpulan bahwa potensi energi Matahari untuk lokasi PLTH di Pantai Sedari didapatkan indeks daily radiation ratarata sebesar $5,17 \mathrm{kWh} / \mathrm{m}^{2} /$ hari. Potensi energi angin di lokasi Pantai Sedari Karawang, rata-rata kecepatan diukur dari ketinggian $50 \mathrm{~m}$ dari permukaan tanah adalah sebesar $3,50 \mathrm{~m} / \mathrm{s}$. Desain pembangkit listrik hybrid menggunakan HOMER terdiri dari PV 0,075 kW, G1 $1 \mathrm{~kW}$ dan Gen 2,7 kW dengan converter $25 \mathrm{~kW}$, diperoleh Biaya Net Total Masa Kini (Total Net Present Cost/NPC) sebesar \$ 82.080,25.

\section{UCAPAN TERIMA KASIH}

Peneliti mengucapkan terima kasih kepada LPPM UNSIKA yang telah memberikan dukungan financial berupa Hibah Internal DIPA UNSIKA 2018 dan semua pihak yang terlibat dalam penelitian ini. 


\section{DAFTAR PUSTAKA}

Asrari, A., Ghasemi, A., \& Javidi, M. H. (2012). Economic evaluation of hybrid renewable energy systems for rural electrification in Iran - A case study. Renewable and Sustainable Energy Reviews, 16(5), 31233130.

https://doi.org/10.1016/j.rser.2012.02.05 2

CDIEMR. (2012). Handbook of Energy and Economics Statistics of Indonesia 2012. 125.

Effendi, A. (2012). Pembangkit Listrik Sel Surya Pada Daerah Pedesaan. 1(1), 19-24.

El-Khattam, W., \& Salama, M. M. A. (2004). Distributed generation technologies, definitions and benefits. Electric Power Systems Research, 71(2), 119-128. https://doi.org/10.1016/j.epsr.2004.01.00 6

Eziyi, I., \& Krothapalli, A. (2014). Sustainable rural development: Solar/Biomass hybrid renewable energy system. Energy Procedia, 57(December), 1492-1501. https://doi.org/10.1016/j.egypro.2014.10. 141

Ifegwu Eziyi. (2013). Distributed Renewable Energy System for Sustainable Rural Development. Florida State University.

Lal, D. K., Dash, B. B., \& Akella, A. K. (2011). Optimization of PV/Wind/MicroHydro/diesel hybrid power system in homer for the study area. International Journal on Electrical Engineering and
Informatics, 3(3), 307-325. https://doi.org/10.15676/ijeei.2011.3.3.4

Lambert, T., Gilman, P., \& Lilienthal, P. (2006). Micropower System Modeling with Homer. Integration of Alternative Sources of Energy, 379-418. https://doi.org/10.1002/0471755621.ch1 5

Rajoriya, A., \& Fernandez, E. (2010). Sustainable energy generation using hybrid energy system for remote hilly rural area in India. International Journal of Sustainable Engineering, 3(3), 219-227. https://doi.org/10.1080/19397038.2010.4 84870

Sitompul, R. (2011). Manual Pelatihan Teknologi Energi Terbarukan yang Tepat Untuk Aplikasi di Masyarakat Pedesaan. Jakarta: PNPM Support Facility (PSF), 45-75.

Suharyadi. (2016). Penggunaan Pompa dengan Mesin Berbahan Bakan LPG sebagai Sarana Irigasi Tanaman Padi di Desa Baktirasa, Kecamatan Sragi, Lampung Selatan. Univesitas Lampung.

Zhou, D., \& Abdullah. (2017). The acceptance of solar water pump technology among rural farmers of northern Pakistan: A structural equation model. Cogent Food \& Agriculture, 3(1).

https://doi.org/10.1080/23311932.2017.1 280882 